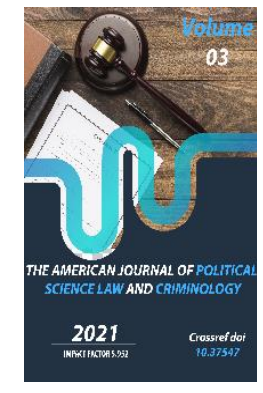

Journal Website: https://theamericanjou rnals.com/index.php/ta jpslc

Copyright: Original content from this work may be used under the terms of the creative commons attributes 4.0 licence.

\section{Scientific Heritage Of Abulhasan Mowardi: Book "Al-Hawiy Al-Kabir" And The Development Of Qur'an Learning In It}

Joraev Ziyovuddin Mukhitdinovich

Doctoral student of the Department of "Islamic Studies and the Study of Islamic Civilization ISESCO", Faculty of Islamic Studies, International Islamic Academy of Uzbekistan; Associate Professor Ph.D of "Source and Archival Studies", Faculty of History, National University of Uzbekistan named after Mirzo Ulugbek, Tashkent Uzbekistan

\title{
ABSTRACT
}

This article describes the work of Abulhasan Movardi, who lived in the years 964-1058 which made a significant contribution to the development of the history of political and legal doctrine and the theory of public administration.

\section{KEYWORDS}

Qur’an, Islam, Ahkom, al-Mavardi, laws, government, election, sunna, Imamat, Sultan.

\section{INTRODUCTION}

Today, the study of written sources in Uzbekistan, in particular, the scientific and comparative study of the manuscript heritage of our ancestors in the field of public administration, the collection of scientific results achieved worldwide is in full swing.

On the eve of its inclusion in the UNESCO "World Memory Program", the National Library of Uzbekistan named after Alisher Navoi, in particular, in cooperation with the service "Rare Books and Rare Manuscripts" published one of the monographs related to theory of translation on scientific research, consistent implementation of such research work as the publication of a research work "Mowardi's Eastern State Doctrine (XI century)" was done by Juraev Z.M [1].

The national and world masterpieces published in 1865-1945 and in subsequent years from the libraries of sultans, emirs, khans and heads of state have been of great historical and scientific significance in the National Library of Uzbekistan. Of great importance is the fact that this category of sources contains sources on political, legal, literary, lexical, and procedural policy. It is very important that one 
of such manuscript sources is the preservation of the works of a medieval thinker - Abulhasan Mowardi.

Detailed information about this scientist is given in many pamphlets and layers [2]. In particular, he is defined as a statesman, jurist, political scientist, lawyer, Islamic scholar, theologian, mutakallim (scholar of Qur'an recitation), literary scholar, sociologist, and methodologist.

\section{THE MAIN PART}

Abulhasan Mowardi, the founder and patron of the "Ahl as-Sunnah wa'l-Jama'ah", and Sunni teachings, wrote in many fields of science and education. He is a scientist who has created a number of works in Shafi'i direction of Islam, especially, Qur'an translation, on the theme of practical-political law, law methods according to his method. It is mentioned in the verses that he was a leading scholar of the Shafi'i jurists, a believing and good scholar who created a number of works in the field of furu al-fiqh (Islamic law), which is a practical field of political jurisprudence [3].

In the Ustuwa region of Movarounnahr, he taught practical-political jurisprudence, usul alfigh (methods of Islamic law) and literary sciences for many years in Basra and Baghdad. Among the Abbasids, Ghaznavids, Seljuks and the Buwayhids he carried out such political and legal activities as an ambassador, a judge, a lawyer, a head of lawyers, and a minister of justice. He is a zealous and perfect man in his sect and has a perfect intellect and scientific potential [4].

Mowardi, as one of the first scholars of the Shafi'i sect of applied political jurisprudence, defended his sect, the pure, enlightened religion of Islam, as a great mujtahid reformer. Anyone who has read his famous work in Shafi'i jurisprudence, "Kitab al-Hawi al-Kabir" ("The Great Encyclopedia"), will testify to the fact that Mawardi had deep and perfect knowledge in his sect, and that he was "Hawi" - an encyclopedic scholar [5].

Mowardi has classified works in all fields of science. Mawardi said, "I have covered the science of jurisprudence in detail in four thousand pages and summarized it in forty pages" [6].

Mawardi, in the above narration, when he said "I have summarized the details of the science of political jurisprudence", he meant "al-Hawi al-kabir", when he siad a short and concise form of the science of jurisprudence, he meant "Kitab al-iqna' fi fiqh al-Shafi'i" [8].

The full title of this book, which relates to the scientific legacy of Abulhasan Mawardi, is called as "al-Hawi al-kabir fi figh madhhab (sect) al-Imam al-Shafi'i (r.a.) and the Huwa sharhu "Mukhtasaru al-Muzanni" ("The Great Encyclopedia: According to the fiqh of the sect of Imam Shafi'i (r.a), "Commentary on Muzanni's Mukhtasar"). Manuscripts of this work are available in the Arabic Manuscripts Fund of World Libraries [9].

This book, which is considered to be the greatest work in the scholar's scientific heritage, is a great legacy that is not based on the habit of classical commentary, but on the understanding of judgments on new issues, as a comparative analysis of different views [10].

It is one of the most comprehensive encyclopedic sources of the Shafi'i sect. As stated in the introduction to "Adab al-Wizara", which published its first edition under Fuad 
Abdulmomin's research, manuscripts of this work are available in various libraries around the world.

In addition to introducing topics related to the "al-Hawi al-kabir" prayers, which include a database in an encyclopedic form, the Hadd and Tazir punishments provide a solution to a number of issues and problems. It is also of great historical significance as it covers financial and economic issues related to zakat, ushur, kharaj / xiraj, jizya (types of Islamic donation) and mines. In parallel with topics related to socio-cultural law, such as marriage, divorce, and testament, personal, legal knowledge is organized and regulated one by one [11].

"Al-Hawi al-Kabir", which is in the status of a Shafi'i encyclopedia of jurisprudence, deals with ethics and prayers, as well as a wide range of disciplines in the science of jurisprudence. In particular, the book also contains knowledge of the method of figh (Islamic law). A manuscript of about 30 volumes of the work is kept in the Department of Shafi'i Fiqh of the "Dar al-Kutub al-Misriyya" (Egyptian National Library) under №82. "Al-Kutub al-Ilmiyya" Publishing House has published a forbidden edition of the work in 18 volumes [12,14].

According to the historical data of the commentators of the later period, Ibn Jawzi in his "Zada al-Musayyyar" and al-Qurtubi's commentary on "al-Jami'u li-Ahkamil in the Qur'an", Imam Mowardi inherited many political insights and wise poetic musannifs (proses). They are mentioned as follows: "Adab ud-dunyo wa ad-din", "Al-Ahkam assultaniya", "Qanun al-vizorat"; and other books including "Siyasatu A'lam anNubuwwat", "Kitab al-Hawi al-Kabir fi Fiqhi al-
Shafi'i" more than 20 volumes, "Kitab Nasihat ul-Muluk", "Kitab Qavoniin al-Visorat wa Siyasat", “Kitab at-tafsir", "Kitab al-iqno" (abbreviated form of "Kitab al-Hawi”), “Kitab adab ul-qazi”, "Kitab a'lam un-nubuwwat", "Kitab tashil an-nazar", "Kitab al-Amsal wa alHikam fi Tafsir al-Qur'an” (“An-Nukat wa al'uyuun”) $[13,15]$ and others.

It was our intention to consider the development of the Qur'an learning in the work of Abulhasan Mowardi "al-Hawi al-Kabir". On the basis of this divine source, we can read the doctrines that he served as the basis for the views of scholars up to his time. In particular, we can see that they were addressed in the following order:

1. From Surat al-Fatiha: 6 times to verses 2,3,5,5,6,6;

2. To Surat al-Baqara: 266 times on the basis of verses such as 1,2,2,6,14,37,41...;

3. To Surah Imran: 60 times on the basis of verses such as 3,4,7,7,7,18,18...;

4. To Surat an-Nisa: 38 times on the basis of verses such as 1,2,3,3,3,3,3,3...;

5. To Surat al-Ma'ida: 209 times on the basis of verses such as $1,1,1,1,1,1,1,1 \ldots$;

6. To Surat al-An'am: 35 times on the basis of verses such as $6,7,19,27,38,60,68,78 \ldots$;

7. To Surat al-A'raf: 33 times on the basis of verses such as 12,12,17,23,26,31,31,33...;

8. Surah Al-Anfal: 44 times on the basis of verses such as 1,1,5,11,12,15,16,16...;

9. To Surat at-Tawba: 77 times on the basis of verses such as 1,2,3,4,4,5,5,6...;

10. To Surah Yunus: 9 times based on verses such as $15,42,43,46,59,88,89,92 \ldots$;

11. To Surah Hud: $5,6,44,44,61,64,64,65, \ldots 16$ times;

12. To Surah Yusuf: 23 times on the basis of verses such as 20,24,29,30,31,31,36,38...; 
13. To Surat ar-Ra'd: 5 times on the basis of verses such as $8,15,21,25,31 \ldots$;

14. To Surah Ibrahim: $4,18,22,36,37 \ldots 5$ times;

15. To Surat al-Hijr: 15 times on the basis of verses such as 9,18,24,30,31,39,40,41...;

16. To Surah An-Nahl: 30 times on the basis of verses such as $1,2,6,8,10,14,16,26 \ldots$;

17. To Surah Al-Isra: 44 times on the basis of verses such as $1,2,4,7,7,8,12,15 \ldots$;

18. To Surat al-Kahf: 22 times on the basis of verses such as 1,2,8,19,23,24,24,29...;

19. To Surah Maryam: 1,4,5,5,6,9,10,10... 23 times;

20. To Surah Ta Ha: 18 times on the basis of verses such as 12,14,15,17,54,55,66,66...;

21. To Surah Al-Anbiya: 22 times on the basis of verses such as 7,15,22,26,47,57,57...;

22. To Surah Al-Hajj: 49 times on the basis of verses such as 5,18,23,25,25,25,26,27...;

23. To Surah Al-Muminun: 18 times on the basis of verses such as 1,2,4,5,5,6,5,6...;

24. To Surah An-Nuur: 75 times on the basis of verses such as 2,2,2,2,2,3,3,3...;

25. To Surat al-Furqan: 14 times on the basis of verses such as $8,23,24,47,48,54,54,60 \ldots$;

26. To Surah Ash-Shu'ara: 21 times on the basis of verses such as $56,64,77,90,165,166,173,192 \ldots$;

27. To Surah An-Naml: 6 times on the basis of verses such as 25,29,29,30,31,91...;

28. To Surat al-Qasas: 14 times on the basis of verses such as 4,8,9,12,26,27,27,27...;

29. To Surah Al-'Ankabut: 9 times on the basis of verses such as $8,14,43,45,48,62,67,67,68 \ldots$;

30. Surat ar-Rum: 24 times on the basis of verses such as 1-5,17,17,17,18,17,18...;

31. To Surah Luqman: 8 times on the basis of verses such as 6,6,6,6,15,15,15,15...;

32. To Surah As-Sajdah: 2 times on the basis of verses such as $15,18 \ldots$;
33. To Surah Al-Ahzab: 61 times on the basis of verses such as $1,5,6,6,6,6,6,9 \ldots$;

34. To Surah Saba: 3 times on the basis of verses such as $14,24,37 \ldots$;

35. Surat al-Fatir: 5 times on the basis of verses such as 1,12,12,15,18...;

36. To Surah Ya-Sin: 7 times on the basis of verses such as 6,39,69,78,78-79,79...;

37. To Surat as-Saffat: 13 times on the basis of verses such as 55,99,102,102,102,103, 104, $105 \ldots$;

38. To Surah Sad: 14 times on the basis of verses such as $6,20,22,24,24,24,26,26 \ldots$;

39. Surah Az-Zumar: 10 times on the basis of verses such as 8,9,18,21,28,30,65,65...;

40. To Surat al-Ghafur: 4 times on the basis of verses such as 11,46,46,60;

41. To Surah Fussilat: 7 times on the basis of verses such as 10,33,37,37,37,37,53 ...;

42. To Surah Ash-Shura: 13 times on the basis of verses such as 1,2,10,13,15,19,25,27...;

43. Surat az-Zukhruf: 10 times on the basis of verses such as 3,15,19,22,22,60,71,77...;

44. To Surah Ad-Dukhan: 4 times on the basis of verses such as 29,43,44,49...;

45. To Surah Al-Jasiyah: 2 times on the basis of verses such as $21.29 \ldots$;

46. To Surat al-Ahqaf: 3 times on the basis of verses such as 15,15,29...;

47. To Surah Muhammad (s.a.v.): 11 times on the basis of verses such as $4,4,4,15,18,22,23,33 \ldots$;

48. To Surat al-Fath: 17 times on the basis of verses such as $1,1,2,18,22,23,24,24 \ldots$;

49. To Surat al-Hujurat: 23 times on the basis of verses such as $1,4,6,6,6,6,6,9 \ldots$;

50. To Surah Qaf: 6 times on the basis of verses such as 1,16,29,39,39,40...;

51. Surah Az-Zariyat: 5 times on the basis of verses such as $13,19,47,59,59 \ldots$; 
52. To Surah At-Tur: 3 times on the basis of verses such as 1,2,21...;

53. To Surah An-Najm: 18 times on the basis of verses such as 3,4,3,4,19,20,21,22...;

54. To Surat al-Qamar: 1 time based on a verse like $1 . .$. ;

55. To Surah Ar-Rahman: 3,4,11,27,27,56,68... 7 times;

56. Surat al-Waqi'a: 11 times on the basis of verses such as 34,35,36,37,55,74,75,77...;

57. To Surah Al-Hadid: 1 time based on a verse such as $22 \ldots$;

58. To Surah Al-Mujadala: 19 times on the basis of verses such as 1,2,2,2,2,3,3,3...;

59. To Surat al-Hashr: 14 times on the basis of verses such as 2,2,5,7,7,7,7,8...;

60. Surat al-Mumtahana: 12 times on the basis of verses such as 1,7,10,10,10,10,10,10...;

61. Going to Surat al-Saff: on the basis of verses such as $4.14 \ldots 2$;

62. To Surah Al-Jumu'ah: 9 times on the basis of verses such as 2,5,9,9,9,9,10,11...;

63. To Surah Al-Munafiqun: 6 times on the basis of verses such as 1,1,2,1,8,10...;

64. To Surah At-Talaq: 23 times on the basis of verses such as $1,1,1,1,1,1,1,2 \ldots$;

65. To Surat at-Tahrim: 6 times on the basis of verses such as $1,1,1,2,4,6 \ldots$;

66. To Surat al-Qalamu: 6 times on the basis of verses such as 17,17,23,24,40,44...;

67. To Surat al-Haqq: 2 times on the basis of verses such as 7.7...;

68. To Surah Al-Ma'ariju: 6 times on the basis of verses such as $24,24,33,35,24,25 \ldots$;

69. To Surah Noah: 9 times on the basis of verses such as 9,10,11,10,11,12,15,16...;

70. To Surah Al-Jinn: 5 times on the basis of verses such as 3,8,16,17...;

71. To Surah Al-Muzammil: 8 times on the basis of verses such as 1,2,3,2,4,6,20,20...;
72. To Surah Al-Muddasir: 10 times on the basis of verses such as $1,4,4,5,5,38,38,42,43,44 \ldots$;

73. To Surah Al-Qiyamah: 8,14,18,25,36,37... 6 times;

74. To Surah Al-Insan: 1,2,7,7,8,21,26,26... 8 times;

75. To Surah Al-Mursalat: 5 times on the basis of verses such as 25,26,27,35,38...;

76. To Surah An-Naba'a: 4 times on the basis of verses such as $8,10,11,14 \ldots$;

77. To Surah An-Nazi'at: 2 times on the basis of verses such as 40,41...;

78. To Surah 'Abasa: 27-30... 4 times;

79. To Surah At-Takwiyr: 3 times on the basis of verses such as 1,6,18...;

80. To Surah Al-Infitaar: 8,19... 2 times;

81. To Surah Al-Mutoffifin: 26... 1 time;

82. To Surah Al-Inshiqoq: 8 times on the basis of verses such as 1,2,16,20,21,21,22...;

83. To Surah Al-Buruj: 1 time on the basis of verse such as $3 . .$. ;

84. To Surah At-Toriq: 7 times on the basis of verses such as $5,6,7,6,6,7,9 \ldots$;

85. To Surah Al-A'laa: 5 times on the basis of verses such as 1,14,15,18,19...;

86. To Surah Al-Gashiah: 1 time on the basis of verse such as $11 . .$. ;

87. To Surah Al-Fajr: 4 times on the basis of verses such as $3,1,2,3 \ldots$;

88. To Surah Al-Balad: 13 times on the basis of verses such as $5,11,11,12,13,12,13,13 \ldots$;

89. To Surah Ash-Shams: 1 time on the basis of verses such as $14,15 \ldots$;

90. To Surah Al-Layl: 2 times on the basis of verses such as 19,20...;

91. To Surah Az-Zuha: 1 time on the basis of verse such as $1 . .$. ;

92. To Surah Ash-Sharh: 1 time on the basis of verses such as $4 \ldots$; 
93. To Surah At-Tiyn: 1 time on the basis of verses such as 3...;

94. To Surah Al-Alaq: 3 times on the basis of verses such as 1,5,19...;

95. To Surah Al-Qodr: 4 times on the basis of verses such as $1,3,4,5 \ldots$;

96. To Surah Al-Bayyinah: 6 times on the basis of verses such as 1,5,5,5,6,7...;

97. To Surah Az-Zalzala: 3 times on the basis of verses such as $7,7,8 \ldots$;

98. To Surah Al-'Adiyat: 3 times on the basis of verses such as $6,7,8 \ldots$;

99. To Surah Al-Qoriah: 4 times on the basis of verses such as $6-9 . .$. ;

100. To Surah Al-Fil: 4 times on the basis of verses such as $1,3-5 \ldots$;

101. To Surah Al-Quraysh: 1 time on the basis of verse such as $2 . .$. ;

102. To Surah Al-Ma'uun: 1 time on the basis of verse such as 7...;

103. To Surah Al-Kawsar: 3 times on the basis of verses such as 1,2,2...;

104. To Surah Al-Kafiruun: 4 times on the basis of verses such as 1,1-3...;

105. To Surah An-Nasr: 1 time on the basis of verse such as $1 . .$. ;

106. To Surah Al-Masad: 5 times on the basis of verses such as 1,1,2,2,4...;

107. To Surah Al-Ihlas: 1 time on the basis of verse such as $1 . .$. ;

108. To Surah Al-Falaq: 1 time on the basis of verse such as $4 .$. can be seen as addressed links. Allah knows.

Based on the above-mentioned consistent research, it can be said that the following six surahs are not used in this play:

64. At-Tag'obuun;

67. Al-Mulk;

102. At-Takasur;

103. Al-Asr;
104. Al-Humaza;

114. An-Nas were not used.

Using the 108 surahs mentioned in Abulhasan Mowardi's “Al-Hawi al-Kabir", it is important to enrich this work with divine concepts, especially in determining the place of his scientific heritage in the development of the Qur'an learning [15-18]. In short, based on the above analysis, it is worth mentioning that one of the sources of Abulhasan Mowardi's work "al-Hawi al-Kabir" is the Qur'an that was given in this book. It has already been revealed from historical, scientific and comparative analysis that he has referred to the verses of the 108 suras in it 1,162 times in order to ensure the validity of his teachings [19-20].

The development of the science of the Qur'an learning from ancient times to the present day is a requirement of the time. As we have seen, whenever our ancestors encountered a problem in any field, they immediately turned to the Book of Allah, the Qur'an, and the hadiths, sought its solution to their problems, and taught us that they had succeeded.

\section{CONCLUSION}

Consistent study of these verses from the Qur'an learning, hadith learning, Shari'a learning, Islamic law, doctrinal, Qur'anic language, theological, political, legal, scientific, literary, social, sociological, philosophical, psychological, religious, secular aspects means to conduct research, if its possible to make inter-galaxy study of the theme. This means that it is a requirement of the time to explain the complex issues of the Qur'an learning to the common people in simple, fluent language. In this case, it is necessary to study, understand, to learn the theme extensively. 


\section{REFERENCES}

1. Juraev Z.M. "Mowardi's Eastern State Doctrine (XI century)". - Tashkent. National Library of Uzbekistan named after Alisher Navoi. - p. 310.

2. رقم حيدر آباد. 1331. 4-ج. -ص. 260 ميزان الاعتدان

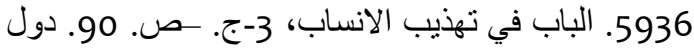

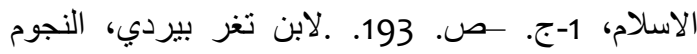

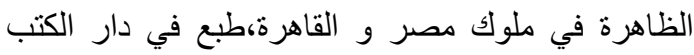

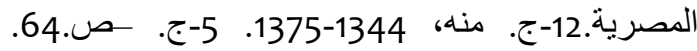

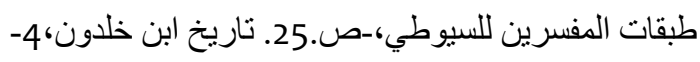

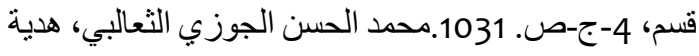

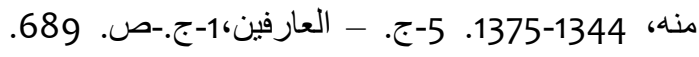
ص.64. طبقات المفسرين للسيوطي،-ص.ص.

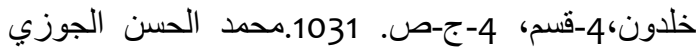

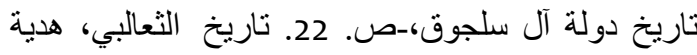

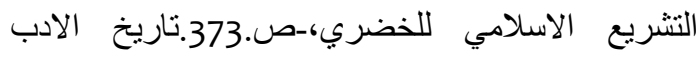

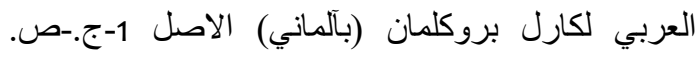

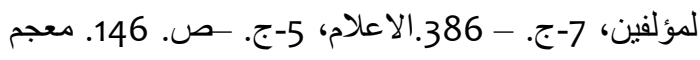
ص. 189. دائرة المعارف الاسلامية مادة (الماوردي) 5-

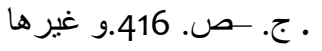

خطيب البغدادي، تاريخ البغداد، 12-ج. - ص. 102. ص. ألماوردي، أدب القاضي.تحقيق محي هلال الغذاني الرحان. بغداد. 1971 بان.

4. El-Maverdi. (1998). Edeb'. Istanbul. p. 8.

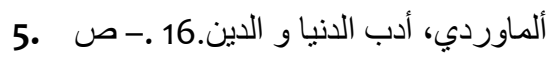

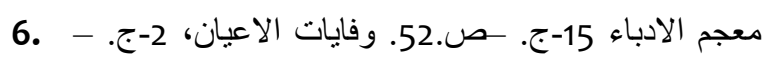
ص. 444

7. اقوت الحموي، ارشاد الاريب الي معريفة الاديب. دار.

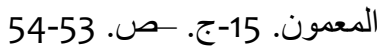

8. Ebu'l-Hasan Habıb el-Maverdı. (2020). ElAhkamü's Sultanıye. Çevıren: Ali Şafak. Islam'da Devlet ve Hilafet Hukuku. Turkiya -Ankara-Istanbul: Bedir by Yayinevi, pp.23.

9. Jo'raev. Z.M. (2018). Al-Mawardi's AlAhkam as-Sultaniyya is an important source on the history of the Muslim East. The history of culture and questions of the historiography of Central Asia. Tashkent. pp.82-89.
10. Abulhasan Maverdi. (2012). Yüce Hedefler Kıtabı. Arabça'dan Çevıren: Bergamalı Ahmed Cevdet Efendı. Hzırlayan: Yaşar Çalışkan. 3-Baskı.

11. Abulhasan Maverdi. Siyaset sanati kitabü'lNasıhatü'l-Mülük // Çevıren: Doç. Dr.Mustfa Sarıbıyık. (2004). Istanbul: Topkapı. Özgü Yayınları. 1-baskı. B. 30. p.455.

12. Abülhasen el-Maverdı. Edebü'l-vezır. Tercüme ve Inceleme Ibrahım Barca. Bılge Yönetıcının Elkıtabı. Islam edenıyetı araştırmaları. Klasık Basım. Istanbul: Topkopı, B.19. p.144 b.

13. Abulhasan Mowardi: Al-Ahkam asSultoniyya. arabic: Ahmad Jodd. (2006). Cairo: Dar ul-hadith, v.1427/M. Ch.10. p. 377.

14. Jo'raev. Z.M. (2018). The structure of the Muslim Eastern state hierarchy in Abulhasan al-Mawardi's Al-Ahkam assultoniyya wa-l-walayat ad-diniyya. The history of culture and questions of the historiography of Central Asia. Tashkent. pp.90-94.

15. Juraev, Z. M. (2019). The intention-a choice or the doctrine of election in mavardi product "Al-ahkom-as-sultoniya va-Ivaloyot ad-diniya". Theoretical \& Applied Science, (7), 446-453. https://dx.doi.org/10.15863/TAS.2019.07.75 .72

16. Juraev Z.M. (2019). Classification of world manuscripts source study of Mavardi product "Ahkom» general characteristic of thesis. Turkish: İpek yolunun yeniden canlandirilmasi: Türkiye-Özbekistan ilişkilerinin dünü bugünü ve geleceği. Istanbul. pp. 195- 199.

17. Juraev Z.M. (2019). The intention - a choice or the doctrine of election in Mavardi product "Al-Ahkom-as-sultoniyava-Ivaloyot ad-diniya”. Rejuvenating silkroad: 
Doi: https://doi.org/10.37547/tajpslc/Volume03Issue09-04

Past, Present and Future of TurkeyUzbekistan Relations. Türkiye-Özbekistan ilişkilerinin dünü bugünü ve geleceği. Istanbul. Istanbul Sabahattin Zaim university publications. pp. 224-232.

18. Muhitdinovich, J. Z. (2020). Al-ahkom assultoniyya va-l-valoyot ad-diniyya in source classification of world manuscripts study of abulhasan mavardi product. Journal of Critical Reviews, 7(3), 438-450.

19. A.Kadiri. Tashkent, 100011, Uzbekistan. Acting associate professor of the Department "Source studies and archival studies" of the Faculty of history of the National University of Uzbekistan named after Mirzo Ulugbek. http://dx.doi.org/10.31838/jcr.07.03.82.

20. Sobirov, J. (2020). International Relations Between Turkic Speaking States. The American Journal of Political Science Law and Criminology, 2(12), 144-149. https://doi.org/10.37547/tajpslc/Volume021 ssue12-22. 